\title{
CCAMLR INITIATIVES TO COUNTER FLAG STATE NON-ENFORCEMENT IN SOUTHERN OCEAN FISHERIES
}

\author{
Rachel Baird*
}

\begin{abstract}
Not all states that have vessels registered under their flag take responsibility for the actions of those vessels and their crews. When enforcement is not carried out by flag states, illegal, unreported and unregulated (IUU) fishing can proliferate and have a serious impact on fish stocks in areas such as the seas around Antarctica. In this article, Rachel Baird evaluates the measures taken by the Commission on the Conservation of Antarctic Marine Living Resources (CCAMLR) to address the issue of IUU fishing. Port state controls, catch documentation schemes, vessel lists and other options are discussed. She concludes that CCAMLR provides some encouraging examples as to how the global problem of IUU fishing may be addressed.
\end{abstract}

\section{INTRODUCTION}

Maritime activities are governed by two fundamental principles: the freedom of the high seas and the exclusivity of flag state jurisdiction over vessels on the high seas. Both principles are integrally linked. A negative expression of the freedom of the high seas is that "[n]o state may validly purport to subject any part of the high seas to its sovereignty."1 ${ }^{1}$ The maintenance of order amongst vessels on the high seas therefore rests primarily on the flag state. ${ }^{2}$ Whilst the exercise of these two key principles is not without limitation under international law, ${ }^{3}$ their defining influence

* Lecturer, TC Beirne School of Law, University of Queensland. The author wishes to thank Dr Denzil Miller, the Executive Secretary of CCAMLR for his insightful comments on this paper.

1 United Nations Convention on the Law of the Sea (10 December 1982) 1833 UNTS 3, art 89. See also article 87 which espouses the general freedom of the high seas and article 90 which provides that every state has the right to sail ships flying its flag on the high seas.

2 The International Law Commission (ILC) emphasised the role of flag states in maintaining order on the high seas in "Report of the ILC on the Work of its Seventh Session 23 April-4 July 1956" (1956) 2 Yearbook of the ILC 279. The exclusive authority of flag states is made evident in United Nations Convention on the Law of the Sea, above n 1, arts 91 and 92.

3 United Nations Convention on the Law of the Sea, above n 1, arts 116-119 outline a number of duties states incur when their nationals fish the high seas. In addition, under article 87(2) high seas freedoms shall be 
remains undiminished. With respect to the exercise of one particular high seas freedom - the freedom of fishing - the combination of non-specific limitations upon this freedom, ${ }^{4}$ and reliance on flag states to exercise control over fishing vessels, has created a lacuna in international fisheries law. In essence, the absence of effective flag state jurisdiction and the inability of third states to exercise jurisdiction over non-flag vessels on the high seas, has placed fishing vessel owners in a position of advantage over regional and coastal state authorities. ${ }^{5}$ Non-enforcement by flag states has facilitated the growth of what is now labelled illegal, unreported and unregulated fishing (IUU fishing). ${ }^{6}$ The incidence of non-compliant and unsustainable fishing has risen dramatically in the past decade, ${ }^{7}$ and the contribution to the global marine capture fisheries crisis by inactive flag states has been recently acknowledged by the Australian Fisheries Minister. ${ }^{8}$

To counter the persistence of IUU fishing, a number of regional fisheries management organisations (RFMOs) have identified alternative methods aimed at deterring and eliminating IUU

exercised with due regard for the interest of other states. Article 94 outlines the duties of flag states with respect to flagged vessels.

4 United Nations Convention on the Law of the Sea, above n 1, arts 87(2), 116-119.

5 It should be noted that the obligations on flag states with respect to flagged fishing vessels will be dependent upon individual membership in relevant RFMOs. For instance non-members of a RFMO are not obliged to comply with conservation measures. See Olav Schram Stokke and Davor Vidas "Regulating IUU Fishing or Combating IUU Operations" in Fish Piracy: Combatting Illegal, Unreported and Unregulated Fishing (OECD, Paris, 2004). This chapter approaches the problem of IUU fishing from the premise that there is a problem with a lack of flag state compliance with respect to flagged fishing vessels.

6 For an outline of the range of activities that might fall within the scope of IUU fishing see article 3 of the Food and Agriculture Organisation of the United Nations International Plan of Action to Prevent, Deter and Eliminate Illegal, Unreported and Unregulated Fishing (FAO, Rome, 2002) [IPOA-IUU].

7 For example the International Commission for the Conservation of Atlantic Tuna (ICCAT) reported in 1992 that non-member landings of Atlantic tuna accounted for as much as 20 per cent of total landings: International Commission for the Conservation of Atlantic Tuna Report of ICCAT Standing Committee on Research and Statistics (ICCAT, Madrid, 1992) 155; the Northwest Atlantic Fisheries Organisation (NAFO) reported more than 30 non-member vessels within the NAFO regulatory area during the late 1980s to1990s: Northwest Atlantic Fisheries Organisation Annual Report of the Northwest Atlantic Fisheries Organisation (NAFO, Dartmouth (Nova Scotia), 1985-1993); within the Convention area of the Commission for the Conservation of Antarctic Marine Living Resources (CCAMLR) the unreported catch (and presumed illegal catch) was estimated to be at least equal to if not more than legal catches: Commission for the Conservation of Antarctic Marine Living Resources Report of the Fourteenth Meeting of the Commission (CCAMLR, Hobart, 1995) 11.

8 In early March 2005, six fishing vessels flagged to non-CCAMLR states of Togo and Georgia were detected adjacent to the Heard and McDonald Islands' exclusive economic zone in an area closed to fishing under CCAMLR conservation measures. Senator McDonald observed in reference to the inaction of flag of convenience states, that "the inability to take action against these vessels on the high seas demonstrated in the clearest possible way the absurdity of current international laws." See, Ian MacDonald, Australian Minister for Fisheries, Forestry and Conservation and Chris Ellison, Australian Minister for Justice and Customs "Flag of Convenience Vessels Flaunt International Rules" (4 March 2005) Press Release. 
fishing, methods which are not dependent upon flag state consent or action. The Convention for the Conservation of Antarctic Marine Living Resources (CCAMLR) ${ }^{9}$ provides the framework for one such RFMO. ${ }^{10}$ The CCAMLR Commission established under article 7 of the Convention, adopted a Catch Documentation Scheme (CDS) in 1999 and implemented an IUU vessel database (IUU database) in 2002. Both initiatives were aimed at deterring IUU fishing for Patagonian toothfish within the Convention area. ${ }^{11}$ Whilst estimates for the 2003/2004 fishing season indicate a marked decline in the incidence of IUU fishing within the Convention area, ${ }^{12}$ this cannot be attributed wholly to new CCAMLR compliance measures. ${ }^{13}$

It can however be argued that the new measures are achieving a degree of quantifiable success. It has been estimated that up to 90 per cent of the global trade in Patagonian toothfish is conducted under the CDS. ${ }^{14}$ All contracting parties, together with non-contracting parties China, ${ }^{15}$

9 Convention for the Conservation of Antarctic Marine Living Resources (20 May 1980) 19 ILM 841 [CCAMLR].

10 In the strict sense CCAMLR is a conservation organisation with an ecosystem based approach to the management of marine living resources, rather than a RFMO as traditionally understood. See CCAMLR, above $\mathrm{n}$ 9, art 1(1). Notwithstanding this distinction, CCAMLR is the organisation charged with the protection of all marine living resources within the Convention area, including the Patagonian toothfish (Dissostichus eleginoides) which is the subject of intense IUU fishing. The Antarctic toothfish (Dissostichus mawsoni) is fished in lesser quantities however remains protected by conservation measures such as the CDS.

11 CCAMLR, above $\mathrm{n} 9$, art 1(1). In essence this encompasses the marine living resources of the area south of 60 degrees South latitude including the area between that latitude and the Antarctic Convergence.

12 Approximately 16.5 per cent of the total toothfish catch was estimated to have been attributable to IUU fishing. See Commission for the Conversation of Antarctic Marine Living Resources Draft Report of the Twenty-Third Meeting of the Commission (CCAMLR, Hobart, 2004) 140 [CCAMLR-XXIII]. This is less than the estimated 37.5 per cent in 2002/2003.

13 The Standing Committee on Implementation and Compliance (SCIC) listed three possible reasons for the decline in IUU fishing activity. These are: the depletion of stocks; vessels reflagging to states which do not participate in the CDS resulting in the receipt of fewer CDS certificates and the impact of compliance measures. See Commission for the Conservation of Antarctic Marine Living Resources Preliminary Report of the Scientific Committee on Observation and Inspection (CCAMLR, Hobart, 2004) 7.12.

14 Denzil Miller, Eugene Sabourenkov and Natasha Slicer "Unregulated Fishing- The Toothfish Experience" in Michael Richardson and Davor Vidas (eds) The Antarctic System for the $21^{\text {st }}$ Century (forthcoming 2005). See also Mary Lack and Glenn Slant "Patagonian Toothfish - Are Conservation and Trade Measures Working?" (2001) 19 TRAFFIC Bulletin 23; and Denzil Miller, Eugene Sabourenkov and David Ramm "Managing Antarctic Marine Living Resources: The CCAMLR Approach" (2004) 19 IJMCL 319, 339.

15 The People's Republic of China has appointed the Ministry of Agriculture as the single authority to sign CDS documents: CCAMLR - XXIII, above n 12, annex 5 paragraph 4.4 . 
Mauritius, ${ }^{16}$ the Seychelles and Singapore, ${ }^{17}$ now implement the CDS. Furthermore, non-CDS toothfish and toothfish products are reportedly fetching lower prices than toothfish certified as being caught in accordance with the CDS. ${ }^{18}$ IUU vessel lists can complement efforts to deter vessels from engaging in IUU fishing, by forming an evidentiary basis for the denial of port access to land or tranship toothfish or the refusal of fishing licence applications or flag registrations. ${ }^{19}$

Whilst there are other potential measures to deter and eliminate IUU fishing, ${ }^{20}$ this article examines the implementation and aims of the CCAMLR CDS and IUU database as measures specifically formulated to deter and eliminate IUU fishing. It concludes that in the absence of effective flag state enforcement these two measures represent a credible means of influencing the conduct of fishing vessels without infringing upon the twin principles of freedom of the high seas and flag state authority. ${ }^{21}$

\section{THE IUU FISHING ENVIRONMENT - IRRESPONSIBLE FLAG STATES AND OPTIONS FOR THIRD STATE ACTION}

IUU fishing is a serious global problem. It has been the subject of numerous conferences and in 2001 the Food and Agriculture Organisation of the United Nations (FAO) adopted an International

16 On 2 October 2004 Mauritius became an acceding state to CCAMLR and acknowledged the assistance of the Australian government in training officials in Mauritius on the implementation of the CDS: "Statement by Mauritius" in CCAMLR-XXIII, above n 12, para 2.12 .

17 Albeit partially, as only re-export documents are authorised: CCAMLR-XXIII, above n 12, para 4.5.

18 Commission for the Conservation of Antarctic Marine Living Resources Report of the Nineteenth Meeting of the Commission (CCAMLR, Hobart, 2000) annex 5 para 2.3 [CCAMLR-XIX]. The Committee noted advice from the Scientific Committee that two markets for toothfish may have developed. One market for toothfish with accompanying CDS documents and another for IUU fish. The later category was reportedly commanding prices in the vicinity of 25-40 per cent lower.

19 For example under Resolution 19/XXI (2002) CCAMLR Contracting Parties and non-Contracting Parties are urged to prohibit landings and transhipments of fish and all fish products from vessels flying flags of non-compliance as well as developing ways to ensure the export or transfer of fishing vessels from their state to a FONC state is prohibited.

20 For example non-flag state enforcement on the high seas which remains contentious or removing the right of known flag of convenience states to offer registration and licences to commercial fishing vessels. Both of these measures involve impinging upon flag state sovereignty in some way. The later proposal involves the notion that these bad states or "bad actors" should perhaps lose the right to exclusive jurisdiction over their vessels because they have failed to fulfil international obligations.

21 It is noted that the problem of IUU fishing runs much deeper than the activity on the seas. There are significant economic drivers which attract transnational investment in what has become a multi-million dollar business. The problem cannot be completely eradicated until the economic incentives are removed. For a discussion on this aspect of IUU fishing see generally, Schram Stokke and Vidas, above n 5; and David Agnew and Colin Barnes "Economic Aspects and Drivers of IUU Fishing: Building a Framework Operations". (OECD, Paris, 2004). 
Plan of Action for the elimination and deterrence of IUU Fishing. ${ }^{22}$ In December 2003 a Ministerial High Seas Task Force (HSTF) on IUU Fishing was established under the auspices of the Organisation for Economic Cooperation and Development (OECD). ${ }^{23}$ The Task Force met in April 2004 and more recently in March 2005. Following the conclusion of the March 2005 meeting, ministerial members agreed upon six priority action areas for the coming year. These include sharing intelligence on IUU vessels, developing a global register of high seas fishing vessels, preparing guidelines on the performance of flag states regarding their high seas vessels, strengthening in-port measures and control over nationals, analysing trade-related measures and addressing RFMO based initiatives and governance issues. ${ }^{24}$

For the purposes of this article, illegal fishing means fishing within a declared exclusive economic zone (EEZ) without the permission of the relevant coastal state or fishing within an RFMO area of application by an RFMO contracting party's flagged vessel (or possibly by a United Nations Fish Stocks Agreement (UNFSA) contracting party) ${ }^{25}$ or fishing in violation of national or international obligations. Unregulated fishing includes fishing within an RFMO area of application by a vessel without nationality or flagged to a non-contracting party and which is not consistent with, or contravenes the conservation and management measures of the relevant RFMO. It also includes fishing on the high seas in general in the absence of flag state authorisation. Unreported fishing comprises misreporting catch levels or failing to report catches. ${ }^{26}$

IUU fishing has been able to persist and arguably, thrive, through the operation of two key principles of international law. ${ }^{27}$ The right to the freedom of fishing on the high seas and the

22 IPOA-IUU, above n 6.

23 OECD "Ministerial Task Force to Tackle Illegal, Unregulated and Unreported Fishing" (1 December 2003) Press Release. Members are the United Kingdom (Chair), Australia, Chile, Namibia and New Zealand.

24 Fisheries and Oceans Canada "Illegal, Unreported and Unregulated (IUU) Fishing and International Fisheries Governance Key Topics at International Meeting" (11 March 2005) Press Release.

25 United Nations Agreement for the Implementation of the Provisions of the United Nations Convention on the Law of the Sea of 10 December 1982 relating to the Conservation and Management of Straddling Fish Stocks and Highly Migratory Fish Stocks (4 August 1995) 2167 UNTS 88; 34 ILM 1542. Article 21(1) provides that a state which is party to the UNFSA but not a member of a relevant RFMO may still find its flagged vessels legitimately boarded and inspected by a member state of that RFMO, on the basis of consent obtained by virtue of ratification of the UNFSA. This Article also implies compliance by the UNFSA state party regardless of membership of the RFMO. See also Article 8(3). On this basis, fishing within a RFMO area of application by a UNFSA contracting party could fall within the definition of IUU fishing.

26 See IPOA-IUU, above n 6, cl 11(3). It is noted that not all unregulated fishing is illegal however it is inconsistent with the aims of sustainable fisheries management.

27 Although there are many more factors relevant to the presence of IUU fishing. See Rachel Baird "Illegal Unreported and Unregulated Fishing: An Analysis of the Legal, Economic and Historical Factors Relevant to its Development and Persistence" (2004) 5 MJIL 299. 
principle of flag state authority have operated to allow fishers to exercise their high seas rights whilst concurrently avoiding regulation if they choose to do so. This avoidance is made possible by the inability of coastal states and RFMOs to take action on the high seas against rogue fishers and the inability or unwillingness of certain flag states to exercise effective control over their flagged fishing vessels.

It should be noted that coastal states do possess specific legal rights in terms of conducting surveillance in their EEZs and apprehending illegal fishers. ${ }^{28}$ Such rights are generally not available to RFMOs with the exception of inspection rights in relation to contracting parties' vessels. During two recent lengthy hot pursuits conducted by Australian authorities ${ }^{29}$ the relevant flag states did not act in a proactive manner to control their flagged vessels or direct them to stop. ${ }^{30}$ Hence, notwithstanding coastal state rights over fisheries within the EEZ, they share have a vested interest in identifying effective strategies for deterring IUU fishing.

Fishers or corporate fishing entities wishing to avoid regulation can conveniently do so through registration with "suitable" flags. This means registration with states which do not exercise their flag state responsibility over fishing vessels and are usually not members of the relevant RFMO. ${ }^{31}$ The term "flag of convenience" has been adopted in the past to label such practices, as has the term "states with open registries". This term denotes the lack of a genuine link between the vessel and the flag state indicating that the registration is one of mere convenience to avoid incurring international or regional obligations and or to take advantage of a particular state's lax attitude with respect to the management of its flagged fishing vessels. ${ }^{32}$ The attractiveness of flags of convenience to IUU fishers is self evident. States operating such registries are generally in breach of international obligations including arising from the United Nations Convention on the Law of the Sea (UNCLOS), ${ }^{33}$ UNFSA, ${ }^{34}$ Compliance Agreement, ${ }^{35}$ and Code of Conduct, ${ }^{36}$ and are not members of RFMOs.

28 United Nations Convention on the Law of the Sea, above n1, art 73(1).

29 The South Tomi in 2001(14 days) and the Viarsa in 2003 (21 days).

30 Togo (South Tomi) was silent and Uruguay (Viarsa), a CCAMLR member state, was contacted by Australian authorities to assist and to exercise its flag state responsibilities and require the Viarsa to accompany the Australian patrol vessel to Fremantle. See Ian MacDonald, Minister for Fisheries, Forestry and Conservation, Chris Ellison, Minister for Justice and Customs, and Sharman Stone, Parliamentary Secretary to Minister for Environment and Heritage "Australian Patrol in Pursuit of Suspected Illegal Fishing Vessel in Sub-Antarctic Waters" (12 August 2003) Press Release.

31 See Schram Stokke and Vidas, above n 5, para 22 and generally paras 17-25.

32 See Agnew and Barnes above n 21, paras 19-23. For commentary on the genuine link concept see Rachel Baird Measures to deter IUU Fishing in the Southern Ocean by CCAMLR and Australia in the absence of Flag State Control (PhD thesis, University of Melbourne, 2005) ch 2 which reviews authorities.

33 United Nations Convention on the law of the Sea, above n 1, art 94. 
Recent studies of the reliance upon flags of convenience by IUU fishers have concluded that a more accurate description of the service provided by states with open registries is that of providing a flag on non-compliance (FONC). ${ }^{37}$ In 2002 CCAMLR adopted this phraseology via Resolution 19/XXI noting that "some flag states, particularly certain non-Contracting Parties, do not comply with their obligations regarding jurisdiction and control according to international law in respect of fishing vessels entitled to fly their flag". ${ }^{38}$ Whilst this new label is undoubtedly more appropriate for RFMOs and international discourse on IUU fishing, it carries no stigma. Flag states disinclined to exercise their general international legal obligations will continue to do so. Messrs Schram Stokke and Vidas have proposed adopting the term "flags of no responsibility" to describe those states which fail to exercise any form of control over flagged fishing vessels. ${ }^{39}$ The reasoning is that few states would be pleased to be labelled "irresponsible" in terms of meeting their international obligations. $^{40}$

It has been observed that in "a world where strong and effective flag state control was exercised, there would be little scope for IUU fishing." ${ }^{41}$ Whilst this observation has merit, there is little economic incentive for states to either decline applications for registration or to take effective enforcement action with respect to non-compliant fishing vessels. Similarly there are significant economic drivers encouraging IUU fishers to seek registration with "suitable" states and this fuels the market for FONC states. There are options however for the international community, RFMOs and coastal states to take action to deter and eliminate IUU fishing in the absence of flag state

34 United Nations Fish Stocks Agreement, above n 25, paras 18-19 and 34-50.

35 Agreement to Promote Compliance with International Conservation and Management Measures by Fishing Vessels on the High Seas (24 November 1993) 1860 UNTS 148; 33 ILM 98. Article 1 contains the general duty to ensure flag vessels do not engage in any activity that undermines the effectiveness of international and conservation measures. Articles 2-8 contain additional responsibilities. This agreement entered into force 24 April 2003. As of 21 March 2005 there were 29 member states. The Seychelles is one significant flag of convenience state which has ratified the Agreement.

36 Food and Agriculture Organisation of the United Nations The Code of Conduct for Responsible Fisheries (FAO, Rome, 1995) arts 6.10 and 6.11. Although the duties outlined in the Code are voluntary, it supports obligations in the Compliance Agreement, UNCLOS and UNFSA..

37 Food and Agriculture Organisation of the United Nations "Port State Control of Fishing Vessels" (FAO Fisheries Circular No 987, Rome, 1995); see also Schram Stokke and Vidas, above n 5, para 23.

38 Resolution 19/XXI (2002) adopted at CCAMLR-XXI.

39 Schram Stokke and Vidas, above n 5, para 23.

40 Schram Stokke and Vidas, above n 5, para 23.

41 David J Doulman "A General overview of some aspects of Illegal, Unreported and Unregulated Fishing" (FAO, Rome, 2000). 
control. The options stem principally from the one activity that all IUU vessels must engage in - at some point they must all unload or tranship their IUU catch. ${ }^{42}$

By establishing and implementing a comprehensive coverage of controls over the unloading and landing of particular fish species, a RFMO can effectively close contracting party ports (and thus markets) which are usually nearest the relevant fishing ground. The CCAMLR CDS aims to do exactly this. By encouraging non-contracting parties to cooperate with regional controls (as the CCAMLR Commission has done) RFMOs can further widen the circumference of controls, effectively forcing IUU vessels to sail further to unload their illegal catches. This then increases the length of each voyage and correspondingly decreases efficiency and profits. Trade controls are integral as a secondary layer of control by preventing the import or export of IUU fish. However there remain a number of shortcomings with the use of trade controls, not the least of which is the lack of standard custom tariff codes amongst states importing or exporting toothfish. ${ }^{43}$

A complimentary mechanism to catch and trade controls is the IUU vessel list recently established by the CCAMLR Commission. ${ }^{44}$ Two separate lists have been established for contracting and non-contracting parties. The implications for vessels included on such lists are discussed further below. It is appropriate now to consider the legal basis for port state catch and trade controls.

\section{PORT STATE CONTROLS UNDER INTERNATIONAL LAW}

Coastal state sovereignty extends the breadth of the territorial sea which includes by definition, internal waters and ports. ${ }^{45}$ The right of coastal states to regulate ports is confirmed further in article 25(2) of UNCLOS which states that the coastal state has the right to take necessary steps to prevent any breach of conditions, to which the admission of ships seeking to enter internal waters or call at a port facility, is subject.

The sovereignty enjoyed by coastal states over their ports has also been confirmed by the International Court of Justice (ICJ) in the Nicaragua case stating "by virtue of its sovereignty a coastal state may regulate access to its ports." 46

42 Increasingly IUU vessels are transhipping catches at sea to avoid coastal state surveillance and enforcement. The CDS applies to transhipments.

43 CCAMLR-XXIII, above n 12, paras 4.8-4.10.

44 CCAMLR Conservation Measure 10-6 (2002) para 4; CCAMLR Conservation Measure 10-7 (2003).

45 United Nations Convention on the Law of the Sea, above n 1, art 2.

46 Case concerning Military and Paramilitary Activities in and against Nicaragua (Nicaragua v United States) (Merits Judgement) [1986] ICJ Rep 14. In this case Nicaragua alleged, inter alia, that the United States had violated the sovereignty of Nicaragua. Relevant to coastal state sovereignty over ports and internal waters, the ICJ found that the laying of mines in the ports of another state affects the sovereignty of that state and 
Both the UNFSA and IPOA-IUU contemplate specific port state measures to prevent and deter IUU fishing. Article 23(1) of the UNFSA states that a port state has both the right and the duty "to take measures, in accordance with international law, to promote the effectiveness of subregional, regional and global conservation." In particular, the UNFSA contemplates that port states may "inspect documents, fishing gear and catch on board fishing vessels, when such vessels are voluntarily in its ports or at its offshore terminals." 47 Port states may regulate to "prohibit landings or transhipments where it has been established that the catch has been taken in a manner which undermines the effectiveness of subregional, regional or global conservation and management measures on the high seas." 48

The IPOA-IUU addresses port state controls in more detail though lacks the binding nature of the UNFSA. ${ }^{49}$ The overarching aim of port state measures is outlined in paragraph 52 which states that measures should be implemented "for port state control of fishing vessels in order to prevent, deter and eliminate IUU fishing." In implementing such controls, port states should require fishing vessels (and vessels involved in fishing activities) to provide: ${ }^{50}$

[R] easonable advance notice of their entry into port, a copy of their authorisation to fish, detail of their fishing trip and quantities of fish on board, with due regard to confidentiality requirement, in order to ascertain whether the vessel has engaged in, or supported IUU fishing.

In circumstances where there is clear evidence that a vessel granted port access has engaged in IUU fishing activity, the port state should not allow the vessel to land or tranship fish in its port. ${ }^{51}$ The IPOA-IUU further calls on port states to develop national, bilateral, multilateral and regional

recognised that it is by virtue of that sovereignty that the coastal state may regulate access to its ports (see para 213).

47 United Nations Fish Stocks Agreement, above n 25, art 23(2).

48 United Nations Fish Stocks Agreement, above n 25, art 23(2).

49 There were 52 member states to the UNFSA as of 11 December 2004

50 IPOA-IUU, above n 6, para 55.

51 The requirement for "clear evidence" places a burden of proof on port states that could restrict the potential of the IPOA-IUU to facilitate far reaching reforms in deterring and eliminating IUU fishing. The CCAMLR CDS, discussed below, operates from the premise that all toothfish imported or exported into the territory of a contracting party or cooperating non-contracting party, must be accompanied by a completed CDS document. Thus there is no requirement for clear evidence of IUU fishing. Incomplete CDS documents trigger a refusal of port access. Furthermore CCAMLR Conservation Measure 19-07 (2003) "Scheme to promote compliance by non-contracting party vessels with CCAMLR Conservation Measures" raises a presumption of non-compliance in that non-contracting party vessels sighted engaged in fishing activities within the Convention area are presumed to be undermining CCAMLR Conservation Measures. Conservation Measure 10-02 (2004) obliges Contracting Parties to licence their flagged vessels meaning unlicensed vessels are presumed to be in contravention of Conservation Measures. 
measures for port state control. ${ }^{52}$ Finally, there is a presumption of non-compliance by non state parties to a particular RFMO, ${ }^{53}$ which is similar to the presumption taken in the application of one CCAMLR Conservation Measure. ${ }^{54}$

In 2000 the Joint FAO/IMO Ad Hoc Working Group on IUU Fishing and Related Matters recognised that whilst fishing vessels were not covered by IMO conventions, there was potential to control vessels engaged in the "transhipment and transport of fish and the resupply of fishing vessels through the application of port state controls over maritime safety, pollution prevention and living and working conditions." 55 The FAO sponsored an Expert Consultation on Port State Measures in 2002 at which a draft Memorandum of Understanding on Port State Measures was adopted. ${ }^{56}$ The draft Memorandum of Understanding contemplates a number of obligations for port states which are framed in similar terms to those cast in the IPOA-IUU. These include:

- a requirement that the foreign fishing vessel provide notification in advance of its intention to seek port access. The notification is to be accompanied with details of the vessel's identity, fishing licence, details of the fishing trip and fish on board;

- the obligation to prevent a vessel from using a port for landing, transhipping or processing fish if the vessel which caught the fish is flying the flag of a non-contracting party or noncollaborating party of a RFMO or has been identified as being engaged in, or supporting, IUU fishing activities ... unless the vessel can establish the catch was caught in a manner consistent with the relevant RFMO conservation and management measures;

- the obligation on port states to refuse port access to vessels that have engaged in IUU fishing (including known offenders); and

- $\quad$ port inspections of vessels and documentation for the purpose of monitoring compliance with relevant conservation and management measures.

In deference to flag state authority, the Memorandum of Understanding stipulates that the flag state should be notified of any non-compliance. However the port state retains the right to deny the landing or transhipment of any fish, to refuse a permit to leave its port pending consultation with the flag State, or to seize the fish.

52 IPOA-IUU, above n 6, paras 61-62.

53 Which have not agreed to co-operate with the particular RFMO, see IPOA-IUU, above n 6, para 63.

54 CCAMLR Conservation Measure 10-07 (2003) para 3. This Measure is discussed further below.

55 Report of the Joint FAO/IMO Working Group on IUU Fishing and Related Matters (Joint FAO/IMO Working Group, Rome, 9-11 October, 2000), table 3.3.

56 Expert Consultation to Review Port State Measures to Combat IUU Fishing (FAO, Rome, 4-6 November 2002), see Food and Agriculture Organisation of the United Nations, above n 37. The Director General of the FAO convened the Expert Consultation to facilitate the implementation of the IPOA-IUU. 
The terms of the draft Memorandum of Understanding were discussed further during the FAO sponsored Technical Consultation to Review Port State Measures to Combat Illegal Unreported and Unregulated Fishing. ${ }^{57}$ The Technical Consultation approved a Model Scheme on Port States Measures to Combat IUU Fishing. ${ }^{58}$ The Model Scheme provides detailed guidance on the measures to be taken by port States in establishing fisheries related port state controls including a checklist of information to be required of foreign fishing vessels seeking port access and instructions for the training of port state inspectors and the conduct of the actual port state inspections. 59

\section{CCAMLR CATCH DOCUMENTATION SCHEME}

\section{A Objectives and Application}

The CCAMLR CDS which has been continually refined since its adoption in 1999, and implementation from May $2001,{ }^{60}$ provides an existing working model for the implementation of port state controls. Indeed in the preamble to the Conservation Measure establishing the CDS, the Commission underlines the "responsibilities of port states to promote the effectiveness of regional fishery conservation measures." Under the CDS, CCAMLR contracting parties are required to take steps to identify the origin of toothfish imported into or exported from their territory. The aim is to establish whether the toothfish was harvested within the Convention area and if so, that it was caught in accordance with CCAMLR Conservation Measures. The Scheme applies to toothfish once it is caught and brought on board the vessel, whereas earlier schemes, such as the International Commission for the Conservation of Atlantic Tuna (ICCAT) Action Plan, target the actual trade in Atlantic bluefin tuna and Atlantic swordfish. ${ }^{61}$ Whilst the CDS is species specific like the initial ICCAT Plans, ${ }^{62}$ the area of intended application is much wider and the market for toothfish is not restricted to CCAMLR member states. ${ }^{63}$ Hence the CCAMLR Commission seeks to target the

57 Held in Rome 31 August - 2 September 2004.

58 See Food and Agriculture Organisation of the United Nations "Report of the Technical Consultation to Review Port State Measures to Combat Illegal, Unreported and Unregulated Fishing" (FAO Fisheries Report No 759, Rome, 2004) appendix E.

59 "Report of the Technical Consultation to Review Port State Measures to Combat Illegal, Unreported and Unregulated Fishing", above n 58, appendix E annex A-E.

60 CCAMLR Conservation Measure 170/VXIII, re-numbered as 10-05 (2004).

61 IICCAT Atlantic Bluefin Tuna Action Plan adopted 1994 (Resolution 93-2) and Atlantic Swordfish Action Plan adopted 1995 (Resolution 95-13).

62 In 1998 ICCAT adopted a wider measure aimed at identifying non-compliant states (whether members or non-members) and applying to any species governed by ICCAT. Resolution by $98-18$ ICCAT concerning the Unreported and Unregulated Catches of Tuna by Large-Scale Longline Vessels in the Convention area.

63 With respect to Bluefin Tuna the primary market state is Japan which received more than 90 per cent of the total Bluefin tuna trade. 
toothfish at the stage of catch so that the application of the CDS could be applied by both member states, and non-members who were willing to cooperate with CCAMLR measures. Non-contracting parties are specifically targeted with an invitation to participate. ${ }^{64}$

The two main objectives of the CDS have been identified as:

- to track landings of, and the world trade in, toothfish caught both within and outside the Convention area; and

- to restrict access to international markets for toothfish from IUU fishing in the Convention area. $^{65}$

In this regard the CDS is an integral part of securing effective port state control. It operates as a trade control by denying the entry of toothfish into the world market without satisfactory documentation. In essence trading without a completed CDS is made more difficult. Valid catch documentation is required for every landing, transhipment, import or export of toothfish. Vessel masters or authorised representatives are required to complete CDS documents on each occasion they seek to land or tranship toothfish. ${ }^{66}$ Similarly, all contracting parties are to ensure landings at their ports, or transhipments to one of their vessels, be accompanied by completed CDS documents. ${ }^{67}$ All exports and imports into contracting party territory are to be accompanied by export-validated catch documents. ${ }^{68}$

\section{B Success of the CDS}

With the announcement by Canada that it was in a position to implement the CDS from 1 April 2004, all CCAMLR contracting parties (including Commission members and acceding states) now comply with the Scheme. ${ }^{69}$ In addition, as mentioned above, a number of non-member states also apply the CDS. ${ }^{70}$

Whilst port state controls on landings, and trade can be effectively implemented on a regional basis through RFMOs, fishing vessels flagged to non-member states can chose to visit the ports of other non-members and thereby avoid the regional controls. This practice will lead to new free ports

64 CCAMLR Conservation Measure 10-05 (2004), paras 5 and 14.

65 Miller, Sabourenkov and Slicer, above n 14, 339.

66

CCAMLR Conservation Measure 10-05 (2004) para 2.

7 CCAMLR Conservation Measure 10-05 (2004) para 3.

CCAMLR Conservation Measure 10-05 (2004) para 8.

69 Commission for the Conservation of Antarctic Marine Living Resources Report of the Twenty Second Meeting of the Commission (CCAMLR, Hobart, 2003) para 7.2 [CCAMLR-XXII].

70 Commission for the Conservation of Antarctic Marine Living Resources Report of the Twenty First Meeting of the Commission (CCAMLR, Hobart, 2002) para 2.8 [CCAMLR-XXI]. See Introductory section above. 
being developed outside the geographical reach of RFMOs. ${ }^{71}$ CCAMLR has had a degree of success in encouraging non-member states to implement the CDS, effectively widening the circle of ports and thus enhancing the effectiveness of the Scheme in regulating IUU fishing. However, CCAMLR has also experienced the development of new port states such as Indonesia and Mozambique, both of which have been approached to implement the CDS. ${ }^{72}$

There have been several instances of port states closing their ports, ${ }^{73}$ and with reference to CCAMLR waters coastal states have on occasions encouraged port states to exercise their jurisdiction over IUU fishing vessels. In 2000 the Polar Viking, a New Zealand flagged vessel, was turned away from the port of Montevideo, Uruguay, on the ground that it had engaged in IUU fishing. ${ }^{74}$ The same year Australia refused entry to two Belize flagged fishing vessels. Both the Cisne Rojo and Cisne Azul were denied entry to Australian ports on the ground that they failed to show a catch of Patagonian toothfish landed previously in Mauritius had been caught in accordance with CCAMLR Conservation Measures. ${ }^{75}$ During the 2003 CCAMLR meeting Namibia reported that following completion of an inspection of the Virgin of Carmen, its refused permission to land toothfish. ${ }^{76}$ In 2004 South African enforcement officers alerted authorities in Singapore to prevent the sale of toothfish suspected of being harvested illegally from South African waters. ${ }^{77}$

Notwithstanding the recent reported success, RFMOs and States have been slow to embrace port state controls. It has been noted as recently as 2003 that "given the obvious legal limitations of measures addressed to the flag state, it is somewhat surprising that port state controls have not been more readily adopted as a means to deter IUU fishing." ${ }^{178}$ The role of some port states in facilitating the IUU trade in toothfish was acknowledged by the Commission in 1997 when it resolved that: ${ }^{79}$

71 The word "free" has be utilised here to denote the fact that the new ports selected by IUU fishing vessels are those that are free from port state controls such as the CCAMLR CDS.

72 CCAMLR-XXI, above n 69, para 7.9-8.8.

73 For a discussion on coastal state legislation see Louise de La Fayette "Access to Ports in International Law" (1996) 11 International Journal of Marine and Coastal Law 1, 6-9.

74 ISOFISH "Toothfish Test Boat Turned Away" (28 June 2000) Press Release. The Polar Viking was registered with New Zealand as a seagoing vessel only.

75 Greenpeace "Australia Leads on Pirate Port Battle" (6 April 2000) Press Release.

76 CCAMLR-XXII, above n 69, para 6.30 and annex 5, paras 3.18-3.19. The vessel was flagged to the Netherlands Antilles. Landing was denied on the ground that the vessel did not possess either a fishing licence, CDS, Vessel Monitoring System, nor have a scientific observer on board.

77 J Yeld "SA Leads Swoop on Suspect toothfish Vessel" (18 October 2004) Cape Arugus Cape Town.

78 C Hedley and L Kengkran "FAO Expert Consultation on Port State Measures to Combat IUU Fishing" [2003] International Fisheries Law and Policy Review (Special Issues) 32.

79 Commission for the Conservation of Antarctic Marine Living Resources Report of the Sixteenth Meeting of the Commission (CCAMLR, Hobart, 1998) para 5.36-5.37 [CCAMLR-XVI]. 
[T] he Commission consider inviting as observers to its next meeting, some States known to be providing, perhaps unwittingly, port access and other services to vessels implicated in illegal and unregulated fishing in the Convention area.

The CCAMLR Secretariat subsequently invited Mauritius and Namibia to attend, as observers, the 1998 CCAMLR Commission meeting. ${ }^{80}$ At that time large quantities of toothfish were moving through Walvis Bay in Namibia and Port Louis in Mauritius annually. It was estimated that tens of thousands of tonnes of toothfish were being processed through Port Louis alone. ${ }^{81}$ Given that Mauritius exports toothfish and toothfish products to the principal toothfish markets: Chile, Hong Kong, Japan, Singapore, Tawian and the United States, securing the cooperation of the Mauritian government in implementing port state controls was a priority for the CCAMLR Commission. ${ }^{82}$ In 2000 the Acting Prime Minister of Mauritius acknowledged the role his state played in the facilitation of IUU fishing in the Southern Atlantic ocean and pledged that his new government would "cooperate fully to fight illegal fishing of toothfish and would welcome the French offer of assistance to the Mauritian team in conducting investigations of fishing ships calling at the Port Louis Harbour." 83 The Mauritian government further stated that it would examine a number of options to deter IUU fishing of toothfish including adopting the CCAMLR CDS (which it now does) and closing Port Louis to fishing vessels suspected of being engaged in IUU fishing. ${ }^{84}$ This stance was confirmed in January 2004 when the Prime Minister of Mauritius announced that inspections will take place to ensure vessels without "proper licensing, without precise CDS papers or without effective flag-State control, would refused unloading and support facilities at Mauritius." 85 In October 2004 Mauritius joined CCAMLR as an acceding state.

Namibia attended the CCAMLR meeting in 1998 and subsequently became a member of the Commission in 2001. ${ }^{86}$ The Namibian official attending the 2001 CCAMLR meeting informed the Commission that the Namibian government was reviewing its Sea Fisheries Act to address the problems raised by Namibia's ports being used to land toothfish caught within the Convention area

80 CCAMLR-XVI, above n 79, para 5.36-5.37.

81 International Southern Oceans Longline Fisheries Information Clearing House "The Invovlement of Mauritius in the Trade in Patagonian Toothfish from Illegal and Unregulated Long Line Fishing in the Southern Ocean and What Might Be Done About It" in ISOFISH Occasional Report No 1 (ISOFISH, Hobart, 1998) para 1.2.

82 Greenpeace "Southern Ocean Pirate Fishing Expedition" (2000) Press Release.

83 Statement by Acting Prime Minister (Mauritian Parliament, 31 October 2000).

84 Statement by Acting Prime Minister, above $n 83$.

85 Minister for Fisheries, Forestry and Conservation "Mauritius Vows to Close its Port to Illegal Fishers" (27 January 2004) DAFF04/016M.

86 Commission for the Conservation of Antarctic Marine Living Resources Report of the Seventeenth Meeting of the Commission (CCAMLR, Hobart, 1998) para 1.7 [CCAMLR-XVII]. 
in contravention of CCAMLR or coastal state measures. ${ }^{87}$ In 2000 the CCAMLR Standing Committee on Observation and Inspection congratulated Namibia in effectively shutting down Walvis Bay as a port for IUU fishing activity. ${ }^{88}$

The Seychelles, another known port state and non-member of CCAMLR, has recently closed its ports to landings of Patagonian toothfish by vessels flagged to non-members of CCAMLR. ${ }^{89}$ The Seychelles' policy change is arguably attributable to the considerable swordfish population within the state's EEZ. In seeking to develop a fishery, the Seychelles will require the cooperation of the international community and openly undermining CCAMLR efforts could hinder this process. ${ }^{90}$ The Seychelles ratified the UNFSA on 20 March 1997. Other known non-contracting parties invited to participate in the CDS include Singapore which implemented the CDS from September 2000 and the People's Republic of China, from July 2001.91

It should be noted that shortly after the introduction of the CDS increasing amounts of toothfish were documented as having been harvested in areas beyond the CCAMLR area of application. ${ }^{92}$ Scientific evidence suggests that it is unlikely the quantities attributed to these areas could in fact be found. ${ }^{93}$ This could be interpreted as a positive impact of the CDS for IUU fishers have altered their practices to avoid regulation. As discussed below, fraudulently completed CDS documents are a problem and it is probable that documents claiming catches from outside the CCAMLR Convention area have been falsified.

\section{Verification of CDS Documentation}

Under the CDS, contracting parties are required to ensure each landing at its port, or transhipment to its vessels, is accompanied by a completed CDS document. Whilst the document must detail the IMO or Lloyd's registration number of the vessel and provide details such as the dates the catch was taken and the CCAMLR statistical subarea or division the toothfish was harvested from (or FAO statistical area if harvested outside the Convention area), there is no mechanism for verifying the accuracy or authenticity of the information provided. This means, the scope for high level fraud through the entry of false dates and/or fishing location details is

87 CCAMLR-XVII, above n 86, para 2.2.0.

88 CCAMLR-XIX, above n 18, annex 5, para 2.56.

89 CCAMLR-XIX, above n 18, annex 5, para 2.56.

90 CCAMLR-XIX, above n 18, annex 5, para 2.56.

91 Miller, Sabourenkov and Slicer, above n 14, 19.

92 CCAMLR-XXI, above n 70, para 7.8. Particularly in areas to the north.

93 CCAMLR-XXI, above n 70, paras 8.2-8.4. 
considerable. Even in the absence of fraud, several port states lack the expertise or resources to rigorously inspect each CDS document or to identify the accompanying catch of toothfish.

The CCAMLR Commission has addressed the above deficiency in part through Resolution 16XIX which provides that flag states participating in the CDS may, on a voluntary basis, take steps to ensure their vessels authorised to fish or tranship toothfish, maintain an operational vessel monitoring system (VMS). A satellite based VMS enables the flag state to monitor a vessel's location and activity and as such has become an integral component in the exercise of flag state responsibility in the context of high seas fisheries. Whilst all CCAMLR contracting parties agreed to implement the VMS from March 1999, ${ }^{94}$ and have further agreed to provide VMS information on the movements of their flagged vessels when entering and leaving the Convention area (and crossing between CCAMLR statistical areas), verification of the accuracy of that data remains a volatile issue. For example when the Viarsa was arrested in 2003 by Australian authorities, the actual location of the vessel did not correspond with the VMS data provided to Uruguay, the flag state. ${ }^{95}$ Whilst there is no obligation to supply VMS data collected through the implementation of Resolution 16-XIX, the Commission has indicated its preference for such an obligation through an optional clause in the CDS. ${ }^{96}$

One option, albeit applied on a voluntary basis, for authenticating the CDS documentation is contemplated in the CDS Conservation Measure. Contracting parties or cooperating non-contracting parties may require additional verification of CDS documents from "flag states by using, inter alia, VMS in respect of catches taken on the high seas outside the Convention area, when landed at, imported or exported from its territory." This option would operate to verify that toothfish claimed to have been caught outside the Convention area has in fact been caught there.

To enhance the effectiveness of the CDS, states should be required to submit VMS data for all catches, whether caught within or outside the Convention area. The trial of a centralised electronic VMS whereby data would be provided to the flag state and the CCAMLR secretariat in "real time" was agreed to at the 2003 CCAMLR meeting. ${ }^{97}$ The centralised-VMS indicates the potential of the VMS to enhance the effectiveness of port state controls to eliminate IUU fishing by reducing the opportunities for accessing legitimate markets through fraudulently completed CDS documents. In 2004 the Commission adopted an amended Conversation Measure 10-04 implementing the centralised-VMS within the Convention area. ${ }^{98}$

94 CCAMLR Conservation Measure 10-04 (2002).

95 D Fickling "Toothfish Poachers Arrested after 7000km Chase" (10 September 2003) Manchester Guardian Weekly Manchester.

96 CCAMLR Conservation Measure 10-05 (2004) para 14.

97 CCAMLR-XXIII, above n 12, annex 5, para 3.31 .

98 CCAMLR-XXIII, above n 12, paras 10.8-10.13. 
An option to further enhance the effectiveness of the CDS by implementing an electronic webbased CDS, was canvassed at the 2003 CCAMLR meeting. ${ }^{99}$ A trial of the proposed Scheme was conducted in 2003 by a limited number of states, including coastal states, port states and market states. ${ }^{100}$ There was wide support for the introduction of electronic reporting, subject to the continuation of the trial for the 2004 intercessional period, with all member states welcome to participate. ${ }^{101}$ The advantage of an electronic web-based CDS is that it can be completed in "real time" which reduces the scope for fraud. ${ }^{102}$ When coupled with the VMS data, also proposed to be obtained in "real time", the net will close upon illegal fishermen, making it increasingly difficult to flout the CCAMLR Conservation Measures. For example, at the 2004 CCAMLR Commission meeting the United States stated it would not accept toothfish not accompanied by an electronically based CDS. ${ }^{103}$

\section{Trade Considerations}

The use of port state controls such as the CCAMLR CDS raises a number of difficulties which must be addressed. First it is open to argue that the CDS amounts to a discriminatory trade measure and as such is contrary to article 11 of the General Agreement on Tariffs and Trade (GATT). ${ }^{104}$ An obvious response would be that the Scheme is a permitted exception under article 20. The application of GATT and article 20 was discussed by the WTO in the Shrimp Turtles dispute. ${ }^{105}$ The dispute centred on the introduction of sea turtle protection measures, which targeted harmful fishing practices which had been shown to cause high levels of turtle mortality. ${ }^{106}$ The United States sought to impose trade restrictions on all shrimp imports not otherwise certified by the Department of State as being caught in accordance with United States sea turtle protection measures. The WTO Panel found that the trade restrictions were prohibited under article 11 of GATT and could not be justified under any of the article 20 exceptions. On appeal the WTO Appellate Body agreed that the

99 CCAMLR-XXII, above n 69 para 7.7.

100 CCAMLR-XXII, above n 69. Australia, Chile, South Africa, UK, Spain, Japan and USA were involved in the 2003 trial.

101 CCAMLR-XXII, above n 69, para 7.8. The trial was endorsed at CCAMLR-XXIII, see Commission for the Conservation of Antarctic Marine Living Resources Report of the Twenty Third Meeting of the Commission (CCAMLR, Hobart, 2004) annex S, para 4.17.

102 Currently contracting states can inspect CDS documents via a secure link on the CCAMLR website.

103 CCAMLR-XXIII, above n 12, para 7.2.

104 General Agreement on Tariffs and Trade (30 October 1947) 55 UNTS 194.

105 United States - Import Prohibition of Certain Shrimp and Shrimp Products (Shrimp Turtles) (12 October 1998) WT/Ds58/AB/R (Appellate Body).

106 K Larson "Fishing for a Compatible Solution: Toothfish Conservation and the World Trade Organisation" (2000) 7 The Environmental Lawyer 123, 143. 
import restrictions on shrimp did fall within article 20(g). However, the Appellate Body concluded that the measure was administered in an arbitrary and discriminatory manner, contrary to the head paragraph (or chapeau) of article 20.107

The CCAMLR CDS is different in some important respects to the Sea Turtle restrictions sought to be imposed by the United States. First, the Scheme is the product of a multilateral organisation with 31 member-states, whilst the restrictions imposed by the United States were unilateral. ${ }^{108}$ Second, the toothfish trade restrictions imposed through the CDS do not apply on the basis of country of origin (as did the Shrimp Turtles restrictions) but on the basis of completed documents, or rather unsatisfactorily competed documents. ${ }^{109}$ The CCAMLR Secretariat has expressed quiet confidence that the CDS is compliant with WTO provisions. ${ }^{110}$ The WTO Committee on Trade and Environment has considered the CCAMLR CDS, but has not reached consensus on the issue. ${ }^{111}$ The WTO Secretariat has however indicated that the CCAMLR Scheme: "Provides examples of appropriate and WTO-consistent (i.e. non-discriminatory) use of trade measures in multilateral environmental agreements." 112

Market state controls over the landing, import, export and re-export dovetail neatly into port state controls. ${ }^{113}$ The CDS seeks to identify (and verify) the origin of the catch, ascertain whether it has been caught in accordance with Conservation Measures and limit trade in IUU toothfish by prohibiting the landing or transhipment of toothfish unless accompanied by satisfactory CDS documents. Information available from CDS data shows the main importers of toothfish are Japan, the United States, the European Community, China and to a lesser degree Canada. ${ }^{114}$ It is also

107 Shrimp Turtles, above $\mathrm{n} 105$.

108 The WTO has expressed a preference for environmentally based trade restrictions formulated through multilateral consensus rather than restrictions imposed unilaterally.

109 Larsen, above n 106, 150

110 Miller, Sabourenkov and Slicer, above n 14, 16. The authors note that the CDS meets three key elements of WTO concern. That is it is non discriminatory, it is transparent in its multilateral nature and has a clear linkage to a policy which aims to conserve the resources concerned.

111 Miller, Sabourenkov and Slicer, above n 14, 16; WTO Committee on Trade and Environment Report of Meeting held 24-25 October 2000 (WT/CTE/M/25, Geneva, 2000).

112 WTO Committee on Trade and Environment Environmental Benefits of Removing Trade Restrictions and Distortions: The Fisheries Sector- Note by the Secretariat (WT/CTE/W/167, Geneva, 2000).

113 Generally trade documentation or controls apply at the point of landing and accompanies fish or fish products entering the international market. Catch certification applies at the point of harvest and applies to the landing or transhipment of fish. See Miller, Sabourenkov and Slicer, above n 14, 16-17.

114 Miller, Sabourenkov and Slicer, above n 14, 20. 
estimated that more than 90 per cent of legitimately caught toothfish is provided by CCAMLR contracting states. ${ }^{115}$

Several CCAMLR members have introduced trade codes to track toothfish imports and exports. The United States, Canada, Norway and Australia reported the introduction of trade codes effective from early 2000. ${ }^{116}$ In 2002 the United States reported to the Commission that the CDS still allowed toothfish to be landed or transhipped under the cover of fraudulent catch documents. ${ }^{117}$ As a significant importer of toothfish the United States, proposed a number of changes to its domestic controls to ensure only legally harvested toothfish and toothfish products entered its territory. These changes include the requirement to obtain a United States dealer permit which would effectively bring the dealer/agent under the jurisdiction of United States law. ${ }^{118}$ It has already been observed that toothfish unaccompanied by appropriate CDS documents has demanded a lower price than toothfish with satisfactorily completed CDS documents. ${ }^{119}$ In 2003 the World Customs Organisation adopted standard custom tariff codes for toothfish products which will assist in tracking the movement of toothfish. ${ }^{120}$

\section{CCAMLR IUU VESSEL LISTS}

The gathering of information about the fishing activities of non-member states' flagged vessels is not in itself innovative. Article 8 of the FAO Compliance Agreement requires states parties to "exchange information amongst themselves, either directly or through the FAO, with respect to activities of fishing vessels flying the flags of non-parties that undermine the effectiveness of international conservation and management measures."121 The IPOA-IUU urges states to act through relevant RFMOs to establish records on those vessels engaged in or supporting IUU fishing and to cooperate in the exchange of information on such vessels. ${ }^{122}$ The UNFSA also emphasises the role of RFMOs by requiring states which are members of a relevant RFMO to "exchange information with respect to the activities of fishing vessels flying the flags of states which are

\footnotetext{
115 Miller, Sabourenkov and Slicer above n 14, 20. These states include: Argentina, Australia, Chile, France, New Zealand, South Africa and the United Kingdom.

116 Commission for the Conservation of Antarctice Marine Living Resources Report of the Eighteenth Meeting of the Commission (CCAMLR, Hobart, 1999) 2.20-2.24. The United States has in fact implemented trade codes since 1998 and the 2000 codes reflect further refinement.

117 CCAMLR-XXI, above n 70, para 8.60.

118 CCAMLR-XXI, above n 70, para 8.60.

119 CCAMLR-XIX, above n 18, annex 5, para 2.3 .

120 CCAMLR-XXIII, above n 12, annex 5, para 4.10.

121 IPOA-IUU, above n 6, cl 11(3).

122 IPOA-IUU, above n 6, paras 80.4-80.5
} 
neither members of the organisation nor participants in the arrangement and which are engaged in fishing operations for the relevant stocks." 123

Converting information collected about IUU fishing vessels into databases is not a CCAMLR initiative either. In 1999 ICCAT established a listing of IUU vessels pursuant to a Resolution calling upon contracting parties (as well as cooperating non-contracting parties, entities or fishing entities) which import frozen tuna and tuna like products to submit detailed information including the name of the vessel which caught and produced the fish, the flag state, the species of tuna caught, the area the catch was taken, vessel registration and details of the vessel owner. ${ }^{124}$ In 2002 ICCAT resolved to establish a list of non-contracting party fishing vessels presumed to have carried out IUU fishing within the Convention area. ${ }^{125}$ The presumption is premised upon the production of evidence that vessels, inter alia, harvest tuna within the Convention area yet are not registered to do so, or fail to report catches to ICCAT, or make false reports, or fish during closed seasons, or tranship catches with vessels on the IUU list. ${ }^{126}$

The establishment of a CCAMLR IUU Vessel List stems from the 2001 meeting during which the Commission accepted advice from the Standing Committee on Observation and Inspection and determined that the Secretariat would compile a list of flag of convenience states. ${ }^{127}$ The Commission agreed that two IUU Vessel Lists be established, one for non-contracting parties whose vessels engage in IUU fishing and a second list detailing non-compliant member states' vessels. ${ }^{128}$

Lengthy discussions took place during the 2003 CCAMLR meeting about the criteria for entry upon, and removal from, the IUU Lists. ${ }^{129}$ The Russian Federation expressed an opinion that: ${ }^{130}$

Conservation Measure 10-06 violates the balance of the rights and duties of a Flag State. ... [To] include a vessel in the proposed IUU Draft List, purely on the grounds of any information about any alleged

123 United Nations Fish Stocks Agreement, above n 25, Article 17(4) applies to RFMO or regional fisheries management arrangements.

124 ICCAT Resolution 98-18. "Unreported and Unregulated Tuna Catches by large-scale Longline Vessels in Convention area" (entered into force 21 June 1999). Replaced by ICCAT Resolution 03-15 "Resolution by ICCAT concerning Trade Measures".

125 ICCAT Resolution 02-23 "Recommendation by ICCAT to establish a list of vessels presumed to have carried out Illegal, Unreported and Unregulated Fishing activities in the ICCAT Convention Area".

126 ICCAT Resolution 02-23, above n 125, para 1. This listing is not exhaustive.

127 Commission for the Conservation of Antarctic Marine Living Resources Report of the Twentieth Meeting of the Commission (CCAMLR, Hobart, 2002) para 5.19 [CCAMLR-XX].

128 CCAMLR Conservation Measure 10-07 (2003); CCAMLR Conservation Measure 10-06 (2004).

129 CCAMLR-XXII, above n 69, paras 8.19-8.67.

130 CCAMLR-XXII, above n 69, para 4.44 . 
violations of this conservation measure. ... [T] he burden of proving this particular vessel did not participate in IUU fisheries ... is on the flag State.

Spain also raised concerns about the undesirable impact of IUU Lists. The Spanish delegate observed that: 131

It appears that this measure is pushing Contracting Parties to rapidly deregister their IUU vessels. As a consequence, IUU vessels and companies associated with them move to operate under the flags of noncompliance, otherwise known as flags of convenience or open registries. ... In doing so we export the problem outside the Commission but the devastating actions of these IUU Vessels and companies still affect the Southern Ocean.

The procedure for including vessels on the proposed IUU Vessel List or the annual IUU Vessel List and considering their subsequent removal is outlined in the applicable CCAMLR Conservation Measures. ${ }^{132}$ Currently a non-contracting party vessel qualifies for reporting to the Commission for review by the Standing Committee on Implementation and Compliance if it is sighted engaging in fishing activities within the Convention area or is denied port access, landing or transhipment. The Standing Committee on Implementation and Compliance then makes recommendations to delete or retain the reported vessels from the proposed list. ${ }^{133}$

The procedure for CCAMLR contracting parties is more complex given the rights of parties to comment on inclusions on the Draft IUU Vessel List. ${ }^{134}$ Given the opportunities for contracting parties to present evidence to the Commission indicating that their identified flag vessels have not engaged in fishing activities in contravention of Conservation Measures; the comments, quoted above, of the Russian delegation at the 2003 CCAMLR meeting, seem unfounded. Rather than imposing the burden of proof of innocence on the flag state, the measure facilitates the provision of information about the activities of flag vessels to clarify questions raised about their fishing activities. The measure states unambiguously that "in order to establish the IUU Vessel List evidence ... shall be required that vessels flying the flags of the contracting party concerned have engaged in one of a list of seven activities including: fishing without a licence; fishing during a closed season; failing to record or declare catches; transhipping fish with vessels already identified for the IUU Vessel List."135

131 CCAMLR-XXII, above n 69, para 8.42.

132 CCAMLR-XX, above n 127.

133 CCAMLR Conservation Measure 10-07 (2003), paras 3-9. This is based on the presumption that the vessel is undermining the effectiveness of CCAMLR Conservation Measures.

134 CCAMLR Conservation Measure 10-06 (2004) paras 1-4, 7-14.

135 CCAMLR Conservation Measure 10-06 (2004) para 5. This listing of criteria is similar to the ICCAT list, see above n 125 
The proposed list of non-contracting party vessels for 2004 contained twelve vessels some flagged to known flag of convenience states including Togo, Honduras and Equatorial Guinea. ${ }^{136}$ The three contracting party vessels listed were flagged to Uruguay. ${ }^{137}$ Whilst a number of refinements to the listing criteria would enhance the transparency of the IUU Vessel List process, ${ }^{138}$ the foundations have been laid for an effective deterrence strategy. Contracting parties whose vessels are included on the IUU Vessel List are required to address the IUU fishing activity which may entail withdrawing vessel registration or licences, the denial of the right to land or tranship catches and the banning of imports from such vessels. ${ }^{139}$ Non-contracting parties whose flag vessels are identified under CCAMLR Conservation Measure 10-07 (2003) are requested to take similar action against their vessels. ${ }^{140}$

\section{CONCLUSION}

IUU fishing, which is very much a creature of the modern law of the sea, is a global problem. It persists and indeed thrives primarily through the operation of two fundamental principles of international law. ${ }^{141}$ The freedom of the high seas enshrines the freedom of fishing, whilst the recognition of flag state sovereignty on the high seas creates a legal environment in which the regulation of fishing vessels rests with just one entity. When this one entity - the flag state - fails to regulate its flagged vessels, or demonstrates an unwillingness to effectively manage its vessels, international law is silent. Absent flag state consent, RFMOs and coastal states cannot enforce conservation and management measures on the high seas, against non-contracting party vessels or foreign fishing vessels, as the case may be. ${ }^{142}$

Hence, the adoption by RFMOs and coastal states of alternative strategies which aim to influence IUU fishing activity by increasing the difficulty of landing or selling IUU fish or attracting unwelcome public scrutiny via IUU Vessel Lists. CCAMLR is one such RFMO which has adopted port and market state controls via the CDS and instituted IUU Vessel Lists. Modelled on the earlier ICCAT strategies, CCAMLR Conservation Measures have already positively addressed the level of IUU fishing within the Convention area. Whilst the CCAMLR Standing Committee on

136 CCAMLR-XXIII, above n 12, appendix 3 to annex 5.

137 CCAMLR-XXIII, above n 12, appendix 3 to annex 5.

138 For example inserting definitions of the terms "fishing" and "transhipment" as recommended by the SCIC. CCAMLR-XXIII, above n 12, annex 5, para 2.13.

139 CCAMLR Conservation Measure 10-06 (2004) para 18.

140 CCAMLR Conservation Measure 10-07 (2003) para 13.

141 Although there are other legal and non-legal factors driving its development. See Baird, above n 27.

142 As discussed above, there is scope under the UNFSA for RFMO member states to board non-member states" vessels based on the latter's ratification of the UNFSA. However even this limited exception is reliant on flag state consent through acceptance of the UNFSA. 
Implementation and Compliance did not definitively associate the reduction in the IUU catch estimate for $2003 / 2004$, to the impact of Conservation Measures, it did identify the measures as a possible factor. Furthermore, the ever widening circle of port states which implement the CDS through the encouragement of non-contracting parties, has had the effect of systematically closing Southern and Indian Ocean ports (and to a lesser extent Atlantic Ocean ports) to IUU fishing vessels. Even if the IUU catch can be landed (at increased expense) further afield from the fishing grounds, increasingly the world market for toothfish is controlled via customs and trade checks imposed by importing states and is regulated by port and market states requiring accompanying CDS documents.

Whilst the model is not perfect, ${ }^{143}$ and there remain a number of issues to be addressed including the process of verifying CDS information and the process of listing vessels on the IUU database, the measures reviewed in this paper are encouraging illustrations of a working model for the elimination of IUU fishing via RFMOs in the absence of effective flag state control.

143 Indeed Schram Stokke and Vidas suggest targeting IUU fishing vessels at the port state level is weak. It is however, preferable to chasing elusive vessels on the open seas and does involve a financial imposition upon the vessel operators and owners via the redirection of the vessel to alternative ports to land the catch or to ports which will accepted transhipped catches. See Schram Stokke and Vidas, above n 5, para 44. 
